\title{
STATUS TANDA PEMBAYARAN PAJAK HASIL BUMI (REFLEKSI KETIDAKHARMONISAN SISTEM RECHT KADASTER DAN FISCAAL KADASTER MEMBERIKAN KEADILAN)
}

\author{
Suparjo Sujadi ${ }^{1}$
}

\begin{abstract}
Abstrak
This article engages Indonesian land and fiscal cadastre disharmony to giving legal certainty and land title security. The issue itself does not free from historical background regarding both land tax and land registration system which has applied until recent time. Many land disputes such as Meruya Jakarta Barat, Polonia Airport Medan land disputes are embarked concerning prior land tax evidence's which then has not accommodate by land registration. More factors that has been made become worse by beraucracy practice and the haves group whom have more power and access to reach winning in many levels through dispute resolutions. The victims that unfairness are deprived peoples who have no same access to land registration and justice.
\end{abstract}

Kata kunci:hukum agraria, pendaftaran tanah, kepastian hukum

\section{Pendahuluan}

Tulisan ini dimaksudkan untuk mencoba memberikan penjelasan berkenaan dengan tanda bukti pembayaran pajak tanah/pajak bumi (sekarang Pajak Bumi dan Bangunan) yang awalnya dikenal dengan 'Pajak Hasil Bumi'. Ide dasar dalam tulisan ini adalah untuk memberikan makna dan implikasi yuridis dari selembar tanda bukti pembayaran pajak. Dari penjabaran ide yang terlihat sederhana itu ternyata di dalam prakteknya menimbulkan kerumitan yang terefleksikan dalam berbagai konflik dan sengketa tanah di berbagai wilayah.

Adanya praktek buruk yang dijalankan birokrasi perpajakan dan pertanahan disertai adanya fenomena yang dari patologi sosial dapat dikatakan adanya faktor kerusakan lain pada para aktor spekulan-spekulan

1 Pengajar (Lektor Kepala) pada Kelompok Hukum Agraria FHUI Depok memperoleh gelar Sarjana Hukum tahun 1993 dan Magister Hukum tahun 2002 yang juga aktif meneliti dan pemerhati hukum pertanahan. 
tanah dari tingkat desa hingga mafia tanah berkekuatan dan bermodal besar yang memiliki afiliasi dengan kekuasaan eksekutif, legislatif, yudikatif, militer. Kedua variabel besar itu melengkapi carut marutnya administrasi perpajakan dan pertanahan yang berdampak pada sejumlah kasus sengketa tanah. $^{2}$

Penjelasan dari perspektif hukum dalam tulisan ini dimaksudkan memberikan pencerahan dan rujukan setidaknya bagi kalangan penggiat kajian, studi di bidang pertanahan khususnya atau setidaknya menjadi referensi sementara untuk mencermati dan memahami berbagai kasus dan sengketa tanah yang memiliki akar permasalahan berkenaan dengan sejarah kebijakan perpajakan khususnya pajak bumi dan pertanahan.

Untuk melengkapi analisis maka diberikan salah satu pendekatan teoritik berkenaan dengan kepastian hukum dengan tetap memperhatikan dan menjunjung tinggi keadilan. Hal ini patut menjadi perenungan sebab jikalau hanya mempergunakan prinsip kepastian hukum yang identik dengan doktrin hukum positif, maka realitas sejarah dan realitas sosial di Indonesia yang masih belum tuntas di bidang perpajakan dan pertanahan maka akan terjebak pada kebenaran materil semata dan meninggalkan keadilan itu sendiri. Keadilan harus ditempatkan pada muara akhir dari hukum dan sistem hukum, hal mana memerlukan kecerdasan intelektual dan kecerdasan emosionalspiritual untuk menjadikan kepastian hukum sebagai milestone menuju keadilan. Prasyarat ideal demikian akan menghindarkan jual beli perkara dan menjadikan sengketa tanah sebagai komoditas untuk memperkaya diri.

Lihatlah pada realitas yang menujukkan pengenaan pajak dan pendaftaran tanah yang masih belum merefleksikan keadilan bagi masyarakat kecil melainkan mengakomodasi pemodal besar dan pemilik akses kekuasaan. Pemungutan pajak (PBB) dilakukan secara insentif melalui perpanjangan tangan hingga kelurahan namun di sisi lainnya masih banyak tanah-tanah penduduk yang notabene tingkat ekonominya rendah yang belum tuntas tersentuh program pendaftaran tanah secara sistematik. Program pendaftaran tanah pertama kali untuk tanah-tanah yang belum terdaftar masih belum mumpuni sebagaimana pernah penulis teliti. ${ }^{3}$

${ }^{2}$ Salah satu kasus terakhir yang berdampak luas dan langsung pada masyarakat berkenaan dengan girik vs sertipkat tanah adalah "Kasus Sengketa Tanah Meruya" di Jakarta Barat yang hingga kini belum jelas kesudahannya, meskipun sudah ada putusan yang berkekuatan hukum tetap (Putusan MA RI No.570/K/Pdt/1999 tertanggal 31 Maret 2000 dan No.2863K/PDT/1999 tertanggal 26 Juni 2001) dan sudah dilanjutkan dengan penetapan eksekusi Nomor 10/2007 dan 11/2007 tertanggal 9 April 2007.

${ }^{3}$ Lihat dalam Suparjo Sujadi "Pendaftaran Tanah (Initial Registraticn) Tanah Bekas Hak Milik Adat di Kantor Pertanahan Kabupaten Bogor dan Kota Depok (Laporan Penelitian 
Kondisi yang demikian menempatkan anggota masyarakat kecil semakin jauh dari jangkauan perlindungan hukum dan kepastian hukum terhadap status pemilikan tanahnya. Logika umum yang berlaku adalah bahwa mereka yang memiliki tanah dengan tanda bukti yang berupa bukti pembayaran pajak hasil bumi dan sekalipun hingga masa sekarang tetap membayar Pajak Bumi dan Bangunan akan cenderung tidak mendaftarkan tanahnya menurut prosedur dan birokrasi pendaftaran tanah yang terakhir diatur dalam Peraturan Pemerintah Nomor 3 tahun 1997 dan Peraturan Menteri Negara Agraria/Kepala BPN No.3 tahun 1997, tentang Pendaftaran Tanah. Hal itu karena rente ekonomi yang tidak sesuai dengan prioritas mereka yang miskin. Besarnya biaya dan ketidakpastian dalam praktek proses terbitnya sertipikat adalah alasan yang logis bagi mereka. ${ }^{4}$

Dampaknya adalah ketika mereka berhadapan dengan aktor-aktor spekulan tanah sebagaimana diuraikan diatas secara logika praktek yang masih terus terjadi adalah bermuara pada kekalahan berperkara dan kehilangan tanah mereka. Inilah yang menjadi keprihatinan berkenaan dengan kepastian hukum dan keadilan yang coba diangkat dalam tulisan ini. ${ }^{5}$

Penjelasan dalam uraian berikut ini akan diberikan dengan permulaan berupa sejarah sistem perpajakan (pajak bumi) di Indonesia sebagai acuan lengkap untuk pehamanan terhadap tanda bukti pembayaran pajak bumi hingga akhir dasawarsa 1990. Untuk menunjukkan korelasi perpajakan dan pemilikkan tanah akan diuraikan pula mengenai pendaftaran tanah sebagai entry gate perlindungan hukum pemilikan tanah yang masih mengacu pada tanda bukti pembayaran pajak bumi sebagai salah satu dokumen penting dalam prosedur pendaftaran tanah pertama kali.

Singkat mengenai Praktek Pelaksanaannya)", Majalah Hukum dan Pembangunan No.2 tahun XXXIV (April-Juni 2004), ISSN: 0215-9687.

${ }^{4}$ Lihat keterangan lain di dalam situs Land Management and Policy Development Project (LMPDP): <http://www.landpolicy.or.id/kajian/13/tahun/2007/bulan/08/tanggal/29/ $\mathrm{id} / 27 />$, diakses tanggal 30 Januari 2008, yang dalam Kajian Penelitian "Penyederhanaan Perangkat Penguasaan Tanah", dalam temuannya menyatakan bahwa efektifitas pendaftaran tanah atau pensertifikatan tanah yang diharapkan sebagai penopang utama pengelolaan pertanahan dan pembangunan yang berkelanjutan, masih jauh dari harapan. Hal ini antara lain disebabkan karena prosedurnya yang panjang, ketidakkejelasan proses, dan pensyaratan yang rumit serta biaya yang tidak terjangkau masyarakat umumnya. Itu semua merupakan permasalahan klasik yang selalu muncul dalam setiap diskusi maupun pendataan di tingkat pemegang hak.

${ }^{5}$ Kasus sengketa tanah Meruya, Bandara Polonia, Alas Tlogo contoh-contoh aktual yang menunjukkan adanya penindasan melalui kekuatan dan kekuasaan. 


\section{Uraian Mengenai Sejarah Sistem Perpajakan (Pajak Bumi) Di Indonesia}

\section{A. Masa Sebelum Berlakunya UU No. 12 Tahun 1985}

Pajak Bumi dan Bangunan bukanlah jenis pajak yang baru. Menurut kronologis sejarahnya Pajak Bumi dan Bangunan dapat dibagi menjadi 3 (tiga) masa yaitu: zaman kerajaan, kolonial, dan kemerdekaan. Pada zaman kerajaan, PBB dikenal dengan nama Drwyahaji, sistem Maro atau Mertelu, dan Pajeg Bumi. Sedangkan Pajak tanah/pajak bumi pada zaman penjajahan, muncul pada awal abad ke 19 di saat pemerintahan di pulau Jawa dipimpin oleh Letjen Sir Standford Raffles yang dianggap sebagai pencetus pajak bumi. Saat itu jenis pajak bumi disebut Land Rent.

Filosofinya adalah bahwa para kepala desa dianggap sebagai penyewa yang harus membayar sewa tanah. Pada zaman Belanda, Land Rent diganti menjadi nama Landrente yang kemudian pada saat pemerintahan Jepang menjadi Land Tax. Pada saat itu pengenaan pajak didasarkan pada tingkat kesuburannya. Setelah proklamasi, nama pajak disebut Pajak Bumi. Akan tetapi kemudian baru pada tahun 1959, pemerintah menghapus Pajak Bumi dan mengganti dengan Pajak Pendapatan Tanah.

Pada tahun 1950 Jawatan Pajak Bumi diubah menjadi Jawatan Pendaftaran dan Pajak Pendapatan Tanah, kemudian diganti lagi menjadi Jawatan Pendaftaran Tanah Milik Indonesia (PTMI) di tahun 1956 yang mempunyai tugas pokok melakukan pendaftaran tanah milik terdaftar sebagai objek pajak.

Untuk tujuan meningkatkan penerimaan Negara, maka kemudian sejak tanggal 29 September 1959 diberlakukan Undang-Undang No. 11 Tahun 1959 tentang Pajak Hasil Bumi. Didalam Penjelasan Umum angka 4 dan 5 Undang-undang No. 11 Tahun 1959 diuraikan bahwa pengenaan pajak hasil bumi menurut ketentuan undang-undang tersebut ditegaskan harus didahului dengan pengukuran tiap-tiap milik dan pengumpulan keterangan-keterangan pengenaan pajak bumi dahulu, yang selama satu setengah abad hasil-hasil dari pekerjaan pendahuluan itu dipakai oleh fihak penguasa untuk mencapai perbaikan kemakmuran rakyat desa. Sumber keterangan-keterangan itu oleh semua pihak diakui kepentingannya. Fungsi yang penting dari hasil pengukuran tersebut terletak pula pada kegunaannya bagi penyelenggaraan suatu pendaftaran tanah didesa, walaupun masih bersifat sederhana. 
Salah satu prinsip yang ditegaskan di dalam Undang-undang No. 11 Tahun 1959 adalah dalam pokoknya perbedaan yang utama antara pajak peralihan dan pajak hasil bumi ialah bahwa kita kembali kepada prinsip pajak kebendaan (zakelijke belasting), dimana titik berat diletakkan pada obyek dari pajak, dalam hal ini tanah milik, prinsip mana masih dipakai dalam pajak Verponding dan pajak Verponding Indonesia.

Pajak hasil bumi berdasarkan Undang-undang No. 11 Tahun 1959 mempergunakan ketentuan-ketentuan pajak hasil bumi dahulu dengan perubahan-perubahan sebagai berikut:

1. Pengenaan pajak hasil bumi dahulu didasarkan melulu atas hasil bersih sedangkan pengenaan pajak hasil bumi ini atas "Nilai Hasil Bumi", suatu pengertian yang mirip dengan istilah Verpondingswaarde pada Undang-undang Verponding.

2. Persenan pajak hasil bumi dahulu untuk tiap-tiap desa berjumlah diantara 8 dan 20 persen dari hasil bersih setahun, sedangkan persenan buat pajak hasil bumi ini berjumlah diantara setengah persen dan satu persen dari nilai hasil bumi atau sama dengan 5 sampai/dengan 10 persen dari hasil bersih setahun, jadih jauh lebih rendah dari pajak hasil bumi dahulu.

Pajak Hasil Bumi dipungut pajak dari semua tanah atas mana berlaku hak kebendaan dan yang tidak dikenakan pajak Verponding atau pajak Verponding Indonesia. Semua tanah yang ada diwilayah Negara dan dimiliki oleh perseorangan, badan hukum dan masyarakat hukum dengan hak kebendaan, dikenakan pajak berdasarkan ketentuan Undang-Undang No. 11 Tahun $1959 .{ }^{6}$

Undang-Undang tersebut juga memberikan pengelompokkan jenis tanah yang dikenai pemungutan pajak hasil bumi, tanah-tanah tersebut di-pasal 1 dibagi dalam jenis-jenis tanah sebagai berikut sebagaimana ditetapkan di dalam Pasal 2, yaitu:

3. tanah pekarangan;

4. tanah-tanah yang menghasilkan seperti:

a. tanah-tanah sawah;

b. tanah-tanah dengan tanaman yang berumur pendek;

c. tanah-tanah dengan tanaman yang berumur panjang;

${ }^{6}$ Lihat dalam Penjelasan Umum angka 7 Undang-undang No. 11 Tahun 1959. Namun sejak berlakunya UUPA mulai tanggal 24 September 1960 tidak ada lagi tanah-tanah Hak Barat dan tanah-tanah hak milik adat. Lembaganya sudah tidak ada lagi, sedang hak-hak atas tanah barat sudah dikonversi oleh UUPA menjadi salah satu hak yang baru. 
d. tanah-tanah lain seperti tambak (empang), tanah pegaraman, hutan nipah, tanah rawa dan lain-lain sebagainya;

5. tanah-tanah yang ditanami tetapi belum memberikan hasil';

6. tanah-tanah yang tidak menghasilkan.

Selain itu ada juga pengecualian tanah-tanah dari pengenaan obyek pemungutan pajak hasil bumi, yaitu:

1. tanah yang baru selesai dibuka dengan pekerjaan yang sangat berat dan sukar atau yang memakan biaya banyak, selama 3 tahun atau kurang8;

2. tanah penggembalaan, tanah keramat dan tanah kuburan, demikian pula tanah-tanah yang diatasnya didirikan sesuatu yang berfaedah bagi umum atau dipergunakan untuk keperluan umum;

3. tanah-tanah percobaan ${ }^{10}$;

4. tanah-tanah transmigrasi selama waktu yang ditetapkan oleh Kepala Jawatan Pajak Hasil Bumi,

5. tanah-tanah lain menurut pertimbangan Kepala Jawatan Pajak hasil Bumi

Pada tahun 1965 nama pajak ini diubah menjadi Iuran Pembangunan Daerah (IPEDA). Pada tahun 1983, pemerintah melakukan reformasi sistem perpajakan nasional melalui pembuatan beberapa peraturan perpajakan. Salah satunya adalah Undang-undang No. 12 Tahun 1985 tentang Pajak Bumi dan Bangunan.

7 Sesuai Penjelasan Pasal 2 pengertian "Tanah yang ditanami tetapi belum memberikan hasil" ialah misalnya tanah-tanah yang baru ditanami dengan tanaman yang berumur panjang (kelapa, teh, kopi, karet dan sebagainya) tetapi belum berbuah/belum dapat dipungut hasilnya. Yang dimaksud dengan "tanah yang tidak menghasilkan" ialah tanah-tanah yang benar-benar tidak dapat dipungut hasilnya dan hanya dimiliki oleh para pemiliknya dengan maksud supaya sebagai pemilik tanah, naik martabatnya.

${ }^{8}$ Sesuai Penjelasan Pasal 3 tanah-tanah yang dibuka adalah tanah yang dibuka baru sesuai dengan Undang-undang yang berlaku.

${ }^{9}$ Sesuai Penjelasan Pasal 3 pada umumnya tanah-tanah tersebut adalah yang berfaedah dan dipakai bagi kepentingan masyarakat.

${ }^{10}$ Sesuai Penjelasan Pasal 3 pengertian "tanah-tanah percobaan", yaitu tanah yang dipergunakan untuk mengetahui hasil tanah-tanah segolongannya; karena penggarapannya harus dilakukan menurut aturan yang tertentu, agar dapat dijamin hasil yang dapat dipercaya, maka dari fihak pemilik tanah percobaan dibutuhkan sekedar tenaga, untuk mana diberikan keringanan dalam bentuk pengecualian pajak. 


\section{B. Masa Sesudah Berlakunya UU No. 12 Tahun 1985 (Status Tanda Bukti Pembayaran Pajak Hasil Bumi dan Implikasi Praktis)}

Sebelum berlakunya Undang-undang No. 12 Tahun 1985 terhadap tanah yang tunduk pada hukum adat telah dipungut pajak berdasarkan Undang-undang Nomor 11 Prp Tahun 1959 dan terhadap tanah yang tunduk pada hukum barat dipungut pajak berdasarkan Ordonansi Verponding Indonesia 1923, dan Ordonansi Verponding 1928

Ada tujuh jenis ketentuan yang mengatur pajak dihapuskan dengan diberlakukannya UU No. 12 Tahun 1985, maka, yaitu:

1. Ordonasi Pajak Rumah Tangga 1908

2. Ordonasi Verponding Indonesia 1923

3. OrdonasiVerponding 1928

4. Ordonasi Pajak Kekayaan 1932

5. Ordonasi Pajak Jalan 1942

6. Pasal 14 huruf j, k, dan UU Darurat Tahun 1957 tentang Peraturan Umum Pajak Daerah

7. Perpu No. 11 Tahun 1959 tentang Pajak Hasil Bumi

Berdasarkan Surat Keputusan Menteri Dalam Negeri No. Sk 26/DDA. 1970 sebagai penjelasan dari peraturan Menteri Pertanian dan Agraria No. 2 tahun 1962 dalam diktum pertamanya : menegaskan bahwa yang dianggap sebagai "tanda bukti hak" dalam Pasal 3 huruf a PMPA No. 2 tahun 1962 adalah:

1. Didaerah-daerah dimana sebelum tanggal 24 September 1960 sudah dipungut pajak (hasil) bumi (landrente) atau verponding Indonesia:

a. Surat pajak (hasil) bumi atau verponding Indonesia yang dikeluarkan sebelum tanggal 24 September 1960, jika antara tanggal 24 September 1960 dan saat mulai diselenggarakan pendaftaran tanah menurut Peraturan Pemerintah No. 10 tahun 1961 terjadi pemindahan hak (jual-beli, hibah atau tukar-menukar) maka selain surat pajak yang dikeluarkan sebelum tanggal 24 September 1960 tersebut di atas wajib disertakan juga surat-surat asli jual-beli, hibah atau tukar menukarnya yang sah (dibuat di hadapan dan disaksikan oleh Kepala Desa/adat yang bersangkutan).

b. Surat Keputusan pemberian hak oleh Instansi yang berwenang, disertai tanda-tanda buktinya bahwa 
kewajiban-kewajiban yang disebutkan di dalam surat keputusan itu telah dipenuhi oleh yang menerima hak.

2. Di daerah-daerah dimana sampai tanggal 24 September 1960 belum dipungut pajak (hasil) bumi (landrente) atau verponding Indonesia.

a. Surat-surat asli jual-beli, hibah atau tukar menukar yang dibuat dihadapan dan disaksikan oleh Kepala Desa/Adat yang bersangkutan sebelum diselenggarakannya pendaftaran tanah menurut peraturan pemerintah No. 10 tahun 1961 di daerah tersebut.

b. Surat Keputusan pemberian hak oleh Instansi yang berwenang, disertai tanda-tanda buktinya bahwa kewajiban-kewajiban yang disebutkan di dalam surat keputusan itu telah dipenuhi oleh yang menerima hak.

Berlakunya UUPA mulai tanggal 24 September 1960 tidak ada lagi tanah-tanah Hak Barat dan tanah-tanah hak milik adat. Lembaganya sudah tidak ada lagi, sedang hak-hak yang ada pun telah dikonversi oleh UUPA menjadi salah satu hak yang baru. Sehubungan dengan itu mulai tahun 1961 tidak ada lagi tanah yang menurut ketentuannya dapat dikenakan Verponding Eropa, Verponding Indonesia dan Landrente atau Pajak Bumi. Maka sejak tahun 1961 tidak ada lagi pengenaan Verponding Eropa, Verponding Indonesia dan Pajak Bumi.

Ketiga pajak tanah tersebut pada tahun 1961 diganti dengan pungutan baru dengan nama Iuran Pembangunan Daerah, disingkat IPEDA. IPEDA inipun kemudian diganti dengan pajak baru, yang diberi nama Pajak Bumi dan Bangunan, disingkat PBB, (LN 1985-68, Penjelasannya dalam TLN 3312)

Berbeda dengan ketiga pajak yang digantinya, pengenaan IPEDA dan PBB tidak dihubungkan dengan status tanah yang bersangkutan, biarpun tanah tetap disebut "obyek pajak" (pasal 2). Bahwa status tanah dan hubungan hukum wajib pajak dengan tanah yang menjadi obyek pajak tidak lagi merupakan faktor penentu pengenaan pajaknya, dapat diketahui dari ketentuan pasal 4 ayat (1): " Yang menjadi subyek pajak adalah orang atau badan yang secara nyata mempunyai sesuatu hak atas bumi, dan/atau memperoleh manfaat atas bumi, dan/atau memiliki, menguasai, dan/atau memperoleh manfaat atas bangunan."

Demikianlah maka setiap orang atau badan yang memperoleh manfaat dari suatu bidang tanah bisa menjadi subyek pajak PBB, bukan hanya mereka yang menjadi pemegang hak atas tanah yang bersangkutan. Dalam pengenaan IPEDA dan PBB juga diterbitkan 
surat pengenaan pajak, yang dalam pemungutan $\mathrm{PBB}$ disebut Surat Pemberitahuan Pajak Terhutang (SPPT). Tetapi karena pengenaannya tidak didasarkan pada adanya hubungan hukum dengan tanah yang merupakan obyek pajak, SPPT, demikian juga petuk IPEDA tidak bisa dipakai sebagai petunjuk bahwa pemegang petuk/SPPT, sebagai wajibpajak mempunyai hak atas tanah tersebut. Seorang okupan illegal pun bisa menjadi pemegang petuk IPEDA/SPPT PBB. Lagi pula dalam SPPT tidak disebutkan status hukum tanahnya. Okupan illegal tanah negara pun anehnya bisa menjadi subyek pajak PBB. Maka dalam penjelasan Pasal 4 ayat (1) Undang-undang No. 12 tahun 1985 tersebut ditegaskan bahwa: "Tanda pembayaran/pelunasan pajak bukan merupakan bukti pemilikan hak".

Namun demikian yang harus dipahami dalam ketentuan hukum adalah bahwa dengan berlakunya UUPA, maka kemudian terjadi pergeseran dalam kaitannya dengan status petuk pajak/tanda pembayaran Pajak Hasil Bumi/Verponding Indonesia sebagaimana dari Yurisprudensi Mahkamah Agung-RI, bahwa petuk pajak oleh Pengadilan juga tidak diterima sebagai tanda bukti pemilikan tanah yang dikenakan pajak, (dinyatakan dalam Putusan Mahkamah Agung tanggal 10 Februari 1960 nomor 34/K/Sip/1960),sebagai berikut:

Surat petuk pajak bumi bukan merupakan suatu bukti mutlak, bahwa sawah sengketa adalah milik orang yang namanya tercantum dalam petuk pajak bumi tersebut, akan tetapi petuk itu hanya merupakan suatu tanda siapakah yang harus membayar pajak dari sawah yang bersangkutan.

Untuk menegaskan prinsip dalam pemahaman hukum yang benar mengenai status petuk pajak bumi tersebut maka kemudian dapat dilihat dengan adanya SURAT EDARAN DIREKTUR JENDERAL PAJAK NOMOR SE - 62/PJ.7/1988, tertanggal 15 agustus 1988, TENTANG PENGGUNAAN NAMA (PENYEBUTAN) FORMULIR PEMBUKUAN, dijelaskan hal-hal mengenai kondisi prosedural administrasi pembayaran pajak bumi yang masih dipergunakan dan penyebutannya secara baku.

Melalui Surat-Surat Edaran Kantor Pusat No. SE-14/PJ.7/1988 tanggal 5 Februari 1988 dan No. SE-33/PJ.7/1988 tanggal 28 Maret 1988, telah dikirimkan contoh-contoh formulir pembukuan data $\mathrm{PBB}$ dengan Kode KP. PBB-36 s/d KP. PBB-41. Adapun formulir-formulir dimaksud adalah: 
1. Register Desa (KP. PBB-36);

2. Buku Carakan/Abjad (KP. PBB-37);

3. Pokok Pajak Bumi dan Bangunan (KP. PBB-38);

4. Daftar Perincian Pajak Bumi dan Bangunan (KP. PBB-39);

5. Himpunan Ketetapan Pajak Bumi dan Bangunan (KP. PBB-40);

6. Daftar Keterangan obyek Pajak Untuk Ketetapan Pajak Bumi dan Bangunan (KP. PBB-41).

Oleh sebab itu dengan penggunaan formulir-formulir tersebut diatas untuk pembukuan data $\mathrm{PBB}$, maka seharusnya penggunaan nama (penyebutan) formulir pembukuan model lama (seperti buku $A$, buku B, buku C, blangko girik/D dan sebagainya) sudah disesuaikan dengan formulir-formulir tersebut diatas. Dijelaskan pula bahwa bahwa formulir:

1. KP. PBB-38 disamakan dengan buku $A$;

2. KP. PBB-39 disamakan dengan buku B;

3. KP. PBB-40 disamakan dengan buku $\mathrm{C}$; dan

4. KP. PBB-41 disamakan dengan girik/petok D.

Namun ternyata masalah penggunaan pajak hasil bumi yang dianggap sebagai tanda bukti pemilikkan tanah masih terus berlangsung di dalam kegiatan masyarakat pada prakteknya. Hal itu tentu saja menimbulkan kerancuan berkenaan dengan pemahaman dari aspek hukumnya secara benar. Bahkan di kalangan KP-PBB pun, masih terjadi penerbitan-penerbitan girik/petuk D/kekitir/keterangan obyek pajak (yang dalam teknis perpajakan dikenal dengan "KP.PBB $41 ")$.

Maka kemudian untuk mentertibkan kondisi yang tidak benar itu, kemudian ditetapkanlah SURAT EDARAN DIREKTUR JENDERAL PAJAK NOMOR SE - 15/PJ.6/1993, tertanggal 27 Maret 1993, TENTANG LARANGAN PENERBITAN GIRIK/PETUK D/KEKITIR/KETERANGAN OBYEK PAJAK (KP.PBB41).

Ditegaskan di dalam surat edaran tersebut bahwa pada kenyataannya sampai saat ini masih banyak Kepala KP.PBB yang menerbitkan Girik/Petak D/Kekitir/Keterangan Obyek Pajak (KP.PBB 41) atau salinannya atas permintaan perseorangan atau badan yang akan digunakan oleh yang bersangkutan sebagai alat pembuktian hak atas tanah. Dan hal ini telah banyak menimbulkan masalah dan mengganggu tugas pokok KP.PBB.

Sebagaimana diketahui berdasarkan ketentuan Pasal 1 ayat (1) dan (2) Undang-undang No. 12 tahun 1985 yang menjadi wajib pajak PBB 
adalah orang atau badan yang secara nyata mempunyai hak atas bumi atau memperoleh manfaat atas bumi dan/atau memiliki, menguasai dan/atau memperoleh manfaat atas bangunan. Dengan demikian wajib pajak PBB yang diadministrasikan di KP.PBB tidak selalu pemilik tanah/bangunan.

Disamping itu di dalam Peraturan Menteri Pertanian dan Agraria No: 2 tahun 1962 Jo. Keputusan menteri dalam Negeri No. 26/DDA/1970 pernah menegaskan bahwa yang dianggap sebagai bukti hak adalah bukti surat pajak (hasil) Bumi yang diterbitkan sebelum tanggal 24 September 1960.

Sehubungan dengan itu maka dengan surat edaran tersebut ditegaskan bahwa terhitung mulai I April 1993 para Kepala KP.PBB tidak dibenarkan menerbitkan Girik/Petak D/Kekitir/Keterangan Obyek Pajak (KP.PBB 41) atau sejenisnya.

Namun kondisi setelah diterbitkannya SURAT EDARAN DIREKTUR JENDERAL PAJAK NOMOR SE - 15/PJ.6/1993, tertanggal 27 Maret 1993, TENTANG LARANGAN PENERBITAN GIRIK/PETUK D/KEKITIR/KETERANGAN OBYEK PAJAK (KP.PBB41), ternyata masih juga belum mengakhiri kondisi di berbagai daerah yang masih berlanjut mengabaikan dan terus melanggar larangan yang ditetapkan di dalam surat edaran tersebut.

Maka kemudian pada tanggal 10 Juni 1993, diterbitkan kembali surat edaran serupa dan lebih menegaskan kembali melalui SURAT EDARAN DIREKTUR JENDERAL PAJAK NOMOR SE 32/PJ.6/1993, TENTANG TINDAK LANJUT LARANGAN PENERBITAN GIRIK, KEKITIR, PETUK D, KETERANGAN OBYEK PAJAK (KP. PBB.41).

Adapun surat edaran tersebut menerangkan bahwa sehubungan dengan Surat Edaran Direktur Jenderal Pajak Nomor: SE-15/PJ.6/1993 tanggal 27 Maret 1993 perihal tersebut di atas, dengan ini ditegaskan mengenai hal-hal sebagai berikut:

1. Para Kepala Kantor Pelayanan PBB tidak dibenarkan lagi memberikan pelayanan yang berhubungan dengan sebagaimana dimaksud pada pokok surat yang meliputi :

a. pembuatan salinan girik karena hilang, rusak, mutasi, pembetulan luas tanah;

b. pemberian keterangan atau riwayat tanah untuk kepentingan pembuatan sertifikat, IMB,

c. pencatatan pada Buku c dalam rangka pembebasan tanah, atas permintaan Bank atau BUPN karena 
girik/daftar keterangan tanah sedang dijaminkan oleh Wajib Pajak;

d. legalisasi fotocopy girik, surat keterangan/riwayat tanah;

e. pengukuran ulang, penunjukan lokasi, dan hal-hal lain yang dikaitkan dengan penentuan status hukum/hak atas tanah.

Dalam hal adanya kebutuhan masyarakat yang memerlukan pelayanan berhubungan dengan penentuan status hukum/hak atas tanah disarankan agar menghubungi Kantor Pertanahan setempat, sesuai dengan ketentuan yang diatur dalam Peraturan Menteri Pertanian dan Agraria Nomor 2 Tahun 1962 tanggal 1 Agustus 1962, Keputusan Menteri Dalam Negeri Nomor : SK.26/DDA/1970 tanggal 14 Mei 1970 juncto Keputusan Mahkamah Agung RI Nomor: Reg. 34.K/Sip/1960 tanggal 10 Pebruari 1960.

2. Dalam hal memenuhi panggilan dari instansi Kepolisian, Kejaksaan, Pengadilan, maupun instansi Pemerintah lainnya yang berkaitan dengan masalah girik, agar tetap berpedoman kepada : Instruksi Menteri Keuangan RI Nomor : 05/IMK.01/ 1978 dan Surat Edaran Direktur Jenderal Pajak Nomor : SE-21/PJ.7/1991 tanggal 26 September 1991.

3. Kepada Kepala Kantor Pelayanan PBB yang wilayah kerjanya berada di eks daerah lama (Jawa, Bali Lombok, Sumbawa, Sulawesi Selatan) diminta untuk segera:

a. Menghubungi Kantor-Kantor Pertanahan setempat untuk menyerahkan Buku $\mathrm{C}$ dengan catatan bahwa Buku $\mathrm{C}$ yang akan diserahkan, terlebih dahulu diteliti dan ditutup dengan garis merah, diberi tanggal, dan diparaf pada setiap halaman oleh Kepala Seksi Pendataan dan Penilaian atau Kepala Seksi Penetapan (contoh lampiran I). Penyerahan Buku C tersebut agar disaksikan oleh Pemerintah Daerah Tk.II dalam hal ini Bagian Pemerintahan dan Bagian Hukum, serta dihadiri oleh instansi terkait lainnya seperti Kepolisian, Kejaksaan, Pengadilan, Bakorstranasda Serah terima tersebut agar dilengkapi dengan Berita Acara sebagaimana contoh lampiran II.

b. Menyebarluaskan Surat Edaran Direktur Jenderal Pajak Nomor : SE-15/PJ.6/1993 tanggal 27 Maret 1993 kepada instansi terkait dan masyarakat. Dengan ini 
ditegaskan bahwa seluruh aturan yang bertentangan dengan surat edaran tersebut seperti surat edaran Nomor: SE-14/PJ.7/1988 tanggal 2 Mei 1988 dan Nomor: SE-26/PJ.6/1988 tanggal 3 April 1988, dinyatakan tidak berlaku lagi.

c. Menyurati Kantor Pertanahan setempat dan para Notaris/PPAT yang intinya agar tidak menggunakan girik sebagai dasar penentuan status hukum/hak atau alas hukum dalam peralihan hak atas tanah. Disamping itu bersama-sama dengan Kantor Pertanahan setempat melakukan penyuluhan kepada masyarakat yang intinya bahwa dalam rangka penerbitan sertifikat maupun pengurusan hak atas tanah, tidak diperlukan lagi girik/kekitir/petukD/daftar keterangan obyek pajak (KP.PBB.41)

Terakhir pada tanggal 11 November 1998, kembali diterbitkan ketentuan SURAT EDARAN DIREKTUR JENDERAL PAJAK NOMOR SE - 44/PJ.6/1998 TENTANG PENEGASAN LARANGAN PENERBITAN GIRIK/PETUK D/KEKITIR/ KETERANGAN OBJEK PAJAK (KP PBB. 41), yang menjelaskan bahwa sehubungan banyak permintaan dari sebagian anggota masyarakat untuk menerbitkan Girik/Petuk D/Kekitir/Keterangan Objek Pajak (KP PBB. 41), akhir-akhir ini maka perlu disampaikan penegasan sebagai berikut:

1. Bahwa ketentuan Larangan Penerbitan Girik/Petuk D/Kekitir/Keterangan Objek Pajak (KP PBB. 41) sebagaimana dimaksud dalam Surat Edaran Direktur Jenderal Pajak Nomor : SE-15/PJ.6/1993 tanggal 27 Maret 1993 perihal: Penegasan Larangan Penerbitan Girik/Petuk D/Kekitir/Keterangan Objek Pajak (KP PBB. 41) masih tetap berlaku.

2. Berkenaan dengan butir 1 di atas, maka apabila ada anggota masyarakat yang mengajukan permintaan data sebagaimana dimaksud, agar dijawab/ditindaklanjuti dengan memperhatikan contoh surat jawaban sebagaimana terlampir (S-1451/PJ.6/1998, tanggal 9 Nopember 1998).

Adanya larangan Penerbitan Girik/Petuk D/Kekitir/Keterangan Objek Pajak (KP PBB. 41) tersebut jika dipatuhi tentu dengan sendirinya sudah mengurangi kekacauan implikasi tanda bukti pembayaran pajak bumi yang "diminati" para spekulan, mafia tanah 
dan menjadi sumber harapan rakyat kecil yang mendambakan pensertifikatan tanah. Hal itu juga mengingat masih belum tuntasnya pendaftaran tanah di Indonesia khususnya tanah-tanah bekas hak milik adat (hak asli Indonesia) yang masih dicirikan dengan bukti berupa tanda pelunasan pajak hasil bumi/petuk pajak dalam pendaftaran terhadap tanah-tanah tersebut (termasuk peralihan haknya) masih dimungkian dalam ketentuan Peraturan Pemerintah Nomor 24 tahun 1997, tentang Pendaftaran Tanah.

\section{Sistem Pendaftaran Tanah dan Perlindungan Hukum Pemilikkan Tanah di Indonesia}

\section{A. Tentang Pendaftaran Tanah di Indonesia dan Aspek Perlindungan Hukum Pemilikkan Tanah}

Dari proyeksi pengaturan pendaftaran tanah dan kepasatian hukum di dalam UU Nomor 5 tahun 1960 sebagiamana diuraikan di dalam Penjelasan Umum angka IV terlihat pada ketentuan dari pasalpasal yang mengatur pendaftaran tanah. Bagi pemegang hak tanahtanah dengan status Hak Milik, Hak Guna Usaha dan Hak Guna Bangunan menurut ketentuan Pasal 23 ayat (2), Pasal 32 ayat (2), dan 38 ayat (2), diwajibkan mendaftarkan tanahnya agar mereka memperoleh kepastian tentang haknya itu. Sesuai dengan tujuannya yaitu akan memberikan kepastian hukum maka pendaftaran itu diwajibkan bagi para pemegang hak yang bersangkutan. Jika tidak diwajibkan maka diadakannya pendaftaran tanah, yang secara jelas akan memerlukan banyak tenaga, alat dan biaya itu, tidak akan ada artinya sama sekali.

Sedangkan Pasal 19 ditujukan kepada Pemerintah sebagai suatu instruksi, agar diseluruh wilayah Indonesia diadakan pendaftaran tanah yang bersifat "rechts-kadaster", artinya yang bertujuan menjamin kepastian hukum. Pendaftaran Tanah akan diselenggarakan dengan mengingat pada kepentingan serta keadaan negara dan masyarakat, keperluan lalu-lintas sosial ekonomi dan kemungkinankemungkinannya dalam bidang personil dan peralatannya.

Menurut ketentuan undang-undang tersebut adanya pertimbangan di atas maka dalam pelaksanaan pendaftaran tanah akan didahulukan penyelenggaraannya di wilayah perkotaan sebagai prioritas awal untuk lambat laun meningkat pada kadaster yang meliputi seluruh wilayah Negara. Sesuai dengan tujuannya yaitu akan memberikan kepastian hukum maka pendaftaran itu diwajibkan bagi para pemegang hak yang 
bersangkutan, dengan maksud agar mereka memperoleh kepastian tentang haknya itu.

Dalam kenyataannya pendaftaran tanah yang diselenggarakan berdasarkan Peraturan Pemerintah Nomor 10 Tahun 1961 tersebut selama lebih dari 35 tahun belum cukup memberikan hasil yang memuaskan. Dari sekitar 55 juta bidang tanah hak yang memenuhi syarat untuk didaftar, baru lebih kurang 16,3 juta bidang yang sudah didaftar. Dalam pada itu, melalui pewarisan, pemisahan dan pemberian-pemberian hak baru, jumlah bidang tanah yang memenuhi syarat untuk didaftar untuk selama Pembangunan Jangka Panjang Kedua diperkirakan akan meningkat menjadi sekitar 75 juta. Hal-hal yang merupakan kendala dalam pelaksanaan pendaftaran tanah, disamping kekurangan anggaran, alat dan tenaga, adalah keadaan obyektif tanah-tanahnya sendiri yang selain jumlahnya besar dan tersebar di wilayah yang luas, sebagian besar penguasaannya tidak didukung oleh alat-alat pembuktian yang mudah diperoleh dan dapat dipercaya kebenarannya.

Selain itu peraturan yang ada sebagai dasar hukum pelaksanaannya dirasakan belum cukup memberikan kemungkinan untuk terlaksananya pendaftaran dalam waktu singkat dengan hasil yang lebih memuaskan.

Pertimbangan-pertimbangan $\mathrm{di}$ atas kemudian menjadi latar belakang penyempurnaan pendaftaran tanah dengan berlakunya PP Nomor 24 tahun 1997 sebagai pengganti PP Nomor 10 tahun 1961. Adapun unsure-unsur penyempurnaan yang diadakan meliputi penegasan berbagai hal yang belum jelas dalam peraturan yang lama, antara lain pengertian pendaftaran tanah itu sendiri, azas-azas dan tujuan penyelenggaraannya, yang disamping untuk memberi kepastian hukum sebagaimana disebut di atas juga dimaksudkan untuk menghimpun dan menyajikan informasi yang lengkap mengenai data fisik dan data yuridis mengenai bidang tanah yang bersangkutan

Berdasarkan Pasal 3 Peraturan Pemerintah Nomor 24 Tahun 1997 dijelaskan bahwa tujuan dari pendaftaran tanah tersebut adalah sebagai berikut:

1. Untuk memberikan kepastian hukum dan perlindungan hukum kepada pemegang hak atas tanah suatu bidang tanah, satuan rumah susun dan hak-hak lain yang terdaftar agar dengan mudah dapat membuktikan dirinya sebagai pemegang hak yang bersangkutan.

2. Untuk menyediakan informasi kepada pihak-pihak yang berkepentingan termasuk pemerintah agar dengan mudah dapat 
memperoleh data yang diperlukan dalam mengadakan perbuatan hukum mengenai bidang-bidang tanah dan satuan-satuan rumah susun yang sudah terdaftar.

3. Untuk terselenggaranya tertib administrasi pertanahan

Selanjutnya di dalam penjelasan Pasal 24 Peraturan Pemerintah Nomor 24 tahun 1997, tentang Pendaftaran Tanah menetapkan bahwa bukti kepemilikan tanah pada dasarnya terdiri dari bukti kepemilikan atas nama pemegang hak pada waktu berlakunya UUPA dan apabila hak tersebut kemudian beralih, bukti peralihan hak berturut-turut sampai ke tangan pemegang hak pada waktu dilakukan pembukuan hak. Adapun alat-alat bukti tertulis yang dimaksudkan antara lain dapat berupa Petuk Pajak Bumi/Landrente, girik, pipil, kerikil dan Verponding Indonesia sebelum berlaku Peraturan Pemerintah Nomor 10 Tahun 1961.

IV. Kepastian Hukum Implikasi Penerapan Recht Kadaster dan Fiscaal Kadaster

\section{A. Kajian dari Sistem Pendaftaran Tanah (Land Cadastre)}

Untuk menjelaskan mengenai pendaftaran tanah secara utuh maka untuk itu perlu diberikan penjelasan mengenai definisi yang dikenal diberbagai literature mengenai Pendaftaran Tanah (Land Cadastre). Dalam aspek linguistik dalam bahasa Latin cadastre adalah "CAPITASTRUM"yang oleh Simpson SR dinyatakan sebagai: "literally 'heads' and so by extension 'taxable land unit" "; atau dalam bahasa Yunani "KATASTIKHON" is meaning literally 'line by line' and so a tax register" ". Sementara Dale memberikan definisi:"A cadastre is a general, systematic and up-to-date register containing information about the quantity (area), value and ownership of land parcels in a country "12; ada juga definisi dari G. Larsson, dalam buku "Land Registration and Cadastral Systems", menyatakan bahwa: "A Cadastre is thus a systematic description of the land units within an area. The description is made by maps that identify the location and

1976.

1 S.R Simpson, "Land Law and Registration", London: Cambridge University,

${ }^{12}$ P.F. Dale, "Cadastral Surveys Within the Commonwealth", HMSO, 1976 bab 1. 
boundaries of every unit, and by records"'/3; atau perhatikan juga definisi singkat dari Hawerk yang mengambil studi pendaftaran tanah di Jerman :"the official register of all parcels and buildings in a state, in which all parcels are described with graphical and textual data". ${ }^{1+}$

Ada juga satu definisi yang lebih koperehensif yang diberikan oleh Henssen:

Cadastre is a methodically arranged public inventory of data concerning properties within a certain country or district, based on a survey of their boundaries. Such properties are systematically identified by means of some separate designation. The outlines of the property and the parcel identifier normally are shown on large-scale maps which, together with registers, may show for each separate property the nature, size, value and legal rights associated with the parcel. IT gives an answer to the question where and how much ${ }^{15}$.

Bandingkan dengan definisi yang diberikan Federation Internationale des Geometres (FIG) atau International Federation of Surveyors yang membedakan pengertian Land Cadastre dengan Land registration, yang menganggap pendaftaran tanah hanya merupakan bagian dari Land Cadastre saja dalam definisi Land Cadastre berikut:

A Cadastre is normally a parcel based and up-to-date land information system containing a record of interests in land (eg. rights, restrictions and responsibilities). It usually includes a geometric description of land parcels linked to other records describing the nature of the interests, and ownership or control of those interests, and often the value

${ }^{13}$ G. Larsson, "Land Registration and Cadastral Systems", New York: Longman Scientific \& Technical, 1991, hal. 16.

14 W. Hawerk, "Grundbuch and Cadastral Systems in Germany, Austria and Switzerland, Modern Cadastres and Cadastral Innovations," makalah dalam Prosiding Seminar sehari yang diadakan dalam the Annual Meeting of Commission 7, Cadastre and Rural Land Management, of the International federation of Surveyors (FIG), Delft, The Netherlands, Mei 1995, pp. 13-26.

${ }^{15}$ Henssen, J. "Basic Principles of The Main Cadastral Systems in The World, Modern Cadastres and Cadastral Innovations," makalah dalam Prosiding Seminar sehari yang diadakan dalam the the Annual Meeting of Commission 7, Cadastre and Rural Land Management, of the International federation of Surveyors (FIG), Delft, The Netherlands, May 1995, pp. 5-12. 
of the parcel and its improvements. It may be established for fiscal purposes (eg. valuation and equitable taxation), legal purposes (conveyancing), to assist in the management of land and land use (eg. for planning and other administrative purposes), and enables sustainable development and environmental protection. Cadastral Reform is concerned with the improvement of cadastral systems, ${ }^{16}$

Sedangkan Land Registration adalah:

Land registration is the official recording of legally recognised interests in land and is usually part of a cadastral system. From a legal perspective a distinction can be made between deeds registration, where the documents filed in the registry are the evidence of title, and registration of title, in which the register itself serves as the primary evidence. Title registration is usually considered a more advanced registration system, which requires more investment for introduction, but provides in principle greater security of tenure and more reliable information. Title registration usually results in lower transaction costs than deed registration systems thereby promoting a more efficient land market. ${ }^{17}$

\section{B. Kajian dari Kepastian Hukum}

Dari berbagai definisi di atas maka dapat diketahui bahwa sistem pendaftaran tanah tidak lepas dari sistem perpajakan (pajak tanah-PBB di Indonesia). Hal ini tentunya dalam model manajemen modern terhadap tanah yang memiliki dua pokok kepentingan Negara, yaitu berkenaan dengan kepentingan devisa dari pajak dan kepentingan rakyat (kewajiban Negara) untuk aspek kepastian dan perlindungan hukum terhadap pemilikan tanah. Land cadastre adalah sistem pendaftaran tanah secara global atau umum yang didalamnya meliputi Land Registration. Pengertian tersebut dapat dilihat dari definisidefinisi diatas dan secara eksplisit sebagaimana yang diberikan FIG.

${ }^{16}$ Lihat selengkapnya dalam situs FIG: <http://www.fig.net/commission7/reports/ cadastre/ atatement_on_cadastre_summary.html >, diakses 1 Februari 2008.

${ }^{17}$ FIG., Ibid. 
Hal yang mirip dapat pula ditemukan di dalam definisi tujuan pendaftaran tanah dim dalam Pasal 19 UU Nomor 5 tahun 1960 dan Pasal 3 PP Nomor 24 tahun 1997 yang memberikan tujuan pendaftaran tanah sebagai bentuk legal cadastre dan meliputi pula kepentingan lainnya yang berupa adanya informasi yang akurat dan sistem admisnistrasi pertanahan yang mumpuni mampu memenuhi kepentingan semua pihak (Negara, rakyat, penguasaha, dan lain-lain). Jadi secara normative ketentuan pendaftaran tanah di Indonesia saat ini sudah sesuai dengan perkembangan modern seiring dengan perkembangan dunia informasi. Namun sayangnya tidak ditunjang dengan perangkat keras sumber daya manusia, infrastruktur pelayanan yang akuntabel serta lemahnya sistem pengawasan internal maupun eksternal yang tercermin masih banyak sengketa tanah.

Pada peringkat masalah yang selebihnya tentunya tidak lepas dari pertanyaan political will pemerintah yang merupakan representasi Negara yang memikul amanah Undang-Undang Dasar Negara RI 1945. Bagaimanakah wujud nyata prinsip-prinsip hukum dasar terkait dengan masalah pemilikan tanah yang setidaknya meliputi:

1. Dimensi persamaan kedudukan dalam hukum dan pemerintahan? Pertanyaan ini dapat dijawab dengan berbagai fakta masih buruknya pelayanan pertanahan yang terungkap dalam berbagai praktek pelayanan yang diskriminatif (seperti idiom 'the have's is have more'), ditambah masih belum mumpuninya kinerja benteng keadilan pada badan-badan peradilan menyangkut sengketa tanah yang masih dirasakan cenderung tidak adil terhadap rakyat kecil $;^{18}$

2. Perlindungan Hak-hak dasar (hak asasi manusia)?

Dari berbagai jenis HAM, setidaknya ada hak dasar yang relevan dipertanyakan berkenaan dengan perlindungan atas harta kebendaannya dari perampasan sewenang-wenang yang nyatanya terjadi dalam berbagai kasus yang kerapkali secara keliru disebut sebagai "pembebasan/pelepasan hak". Hal ini lebih tragis dalam

18 Tak kurang dari lima ribuan warga Forum Masyarakat Sari Rejo (Formas) menutup akses masuk ke Bandara Polonia, Medan, Sumatera Utara dalam aksi demo yang dilakukan di depan Bandara Polonia, Senin, 7 Januari 2008. Penutupan akses ke Bandara Polonia dilakukan selama 2,5 jam. Formas juga menuntut agar BPN (Badan Pertanahan Negara) mengeluarkan sertifikat tanah masyarakat yang berpegang kepada putusan MA dengan nomor register No.229K/Pdt/1991 tanggal 18 Mei 1995. Selengkapnya lihat dalam situs: <http://batampos.co.id/Diiringi-Tor-tor-Warga-Blokir-Bandara-Polonia.html >, diakses tanggal 1 Februari 2008. 
hal pemilik tanah tidak memiliki sertipikat (hanya berupa bukti pembayaran pajak hasil bumi/girik saja). ${ }^{19}$

3. Jaminan akan menikmati sebesar-besar kemakmuran rakyat?

Adanya fakta sebagai uraian awal tulisan ini cukup kiranya menjadi jawaban menyangkut pajak tanah dan akses memperoleh sertipikat yang masih belum adil bagi kebanyakan rakyat miskin. Atau ditambah dengan pertanyaan bagaimana alokasi devisa dari pemungutan $\mathrm{PBB}$ bagi rakyat kecil yang harus antri beras, minyak tanah, perawatan kesehatan? Sementara secara umum dan ideologis berkenaan dengan masalah besar alokasi kemakmuran melalui program landreform yang mulai didengungkan kembali oleh pemerintah. ${ }^{20}$

Analisis yang dapat diajukan di sini bila menerapkan ajaran positivist yang meletakkan hukum dasar pada level konstitusi maka terkait dengan jaminan kepastian hukum tentunya dapat dijelaskan bahwa masih belum tercapai. Hal ini akhirnya akan terkait dengan ranah politik yang mempengaruhi jalannya pemerintahan yang sesungguhnya tidak lain memiliki panduan hukum dasar, melaksanakan hukum dasar dalam penyelenggaraan pemerintahan Negara. $^{21}$

${ }^{19}$ Mengenai kekeliruan dalam penyebutan tersebut tentunya secara hukum dapat dijelaskan bahwa contohnya dalam berbagai kasus perolehan tanah untuk kepentingan umum yang dilakukan secara keliru, manipulatif dan melanggar UU Nomor 20 tahun 1961 tentang Pencabutan Hak atas Tanah dan Benda-Benda di atasnya. Kekeliruan itu dapat dibedakan dalam dua kelompok besar yaitu dalam tataran normatif dalam bentuk pengaturan mengenai perolehan tanah untuk kepentingan umum di dalam berbagai peraturan terakhir seperti di dalam Perpres Nomor 65 tahun 2006; dan kedua dalam tataran praktis yang dapat dilihat dalam berbagai kasus: seperti kasus proyek tol lingkar luar Jakarta-JORR yang menerapkan gusur dulu, urusan belakangan dimana pemilik tanah belum sepakat dan belum menerima kompensasi/ganti kerugian, namun sudah tidak dapat menempati tanah dan rumahnya yang telah digusur. Dalam literature hukum tanah praktek itu bukan pembebasan/pelepasan hak, melainkan penyitaan paksa atau confiscation.

${ }^{20}$ Lihat dalam Suparjo Sujadi Masalah-Masalah Hukum Aktual dalam Wacana Agraria di Indonesia, dalam Jurnal Hukum dan Pembangunan No.1 tahun ke 37 (JanuariMaret 2007), ISSN: 0215-9687, hal .90-118.

${ }^{21}$ Salah satu acuan yang dipergunakan dalam tulisan ini mengenai sistem hukum dan tatanan/hierarki perundang-undangan dalam Hans Kelsen [trans.Anders Wedberg], General Theory ofLaw and State. New York:Russel and Russel:1994, khususnya Bab XI.The Hierarchy of the Norms, hal 123-161. 
Untuk itulah tulisan ini tidak dapat memberikan deskripsi lengkap mengenai masalah kepastian hukum, namun juga menggugah untuk merenungkan kembali berbagai persoalan yang masih terus ada.

\section{Penutup}

Dalam bagian penutup ini akan disampaikan resume singkat untuk menegaskan pokok pikiran yang menjadi analisis berkenaan dengan masalah ketidakharmonisan sistem pendaftaran tanah dan pemungutan pajak bumi (PBB) dalam kaitannya dengan kepastian dan perlindungan hukum. Adapun yang dapat diajukan sebagai resume singkatnya dalam bentuk simpulan penting adalah sebagai berikut:

1. Masih banyak segketa tanah yang bersumber dari masalah tanda bukti pembayaran Pajak Hasil bumi yang terkait dengan sejarah pemungutan pajak kemudian pada perkembangan terakhir diganti dengan PBB. Hal itu terbukti dengan masih adanya praktek penerbitan keterangan pajak (KP-PBB 41) berupa girik, meskipun sudah ada Surat Edaran Dirjen Pajak yang tegas dan jelas melarangnya. Pergantian metode pemungutan pajak tersebut secara birokratis ternyata masih belum adequate atau mumpuni untuk menciptakan keadilan secara komperehensif.

2. Implikasi sistem perpajakan tersebut dalam angka 1 juga diikuti dengan sistem palayanan pendaftaran tanah yang sama-sama kurang mumpuni juga. Padahal sistem pendaftaran tanah yang diamanahkan Pasal 19 UU Nomor 5 tahun 1960 secara jelas dan tegas ditujukan untuk memberikan kepastian dan perlindungan hukum.

3. Kombinasi kedua faktor tersebut telah dimanfaatkan baik secara langsung maupun tidak langsung oleh para aktor spekulan, mafia tanah, mafia peradilan untuk secara efektif memanfaatkan keburukan sistem perpajakan dan pendaftaran tanah untuk memperoleh keuntungan secara tidak bermoral dan melawan hukum.

4. Pada ranah politik pemerintah masih mencerminkan belum memihak dan memberikan prioritas mendekatkan dan memberikan keadilan bagi rakyat kecil dalam rangka memperoleh akses pendaftaran dan pensertifikatan tanah; serta dalam skala yang lebih luas belum merata akses untuk menguasai dan memiliki tanah dengan gagalnya program landreform di masa lalu dan ide kebijakan melaksanakan landreform menjelang pasar 
global yang liberal yang belum memberikan titik terang jaminan kepastian hukum, karena absurd-nya konsep kebijakan yang dirancang. 


\section{Daftar Pustaka}

\section{Buku dan Makalah}

G. Larsson, Land Registration and Cadastral Systems, New York: Longman Scientific \& Technical, 1991.

Hawerk, W. "Grundbuch and Cadastral Systems in Germany, Austria and Switzerland, Modern Cadastres and Cadastral Innovations". makalah dalam Prosiding Seminar sehari yang diadakan dalam the Annual Meeting of Commission ,.Cadastre and Rural Land Management, of the International federation of Surveyors (FIG). Delft, The Netherlands, Mei 1995.

J, Henssen. "Basic principles of the main cadastral systems in the world, Modern Cadastres and Cadastral Innovations". Makalah dalam Prosiding Seminar sehari yang diadakan dalam the Annual Meeting of Commission 7, Cadastre and Rural Land Management, of the International federation of Surveyors (FIG). Delft, The Netherlands, Mei 1995.

Kelsen, Hans [trans.Anders Wedberg].General Theory ofLaw and State. New York:Russel and Russel: 1994.

P.F. Dale, Cadastral surveys within the Commonwealth, HMSO, 1976.

Simpson, S.R. Land Law and Registration, London: Cambridge University,1976.

Sujadi, Suparjo. Pendaftaran Tanah (Initial Registration) Tanah Bekas Hak Milik Adat di Kantor Pertanahan Kabupaten Bogor dan Kota Depok (Laporan Penelitian Singkat mengenai Praktek Pelaksanaannya), Majalah Hukum dan Pembangunan No.2 tahun XXXIV (April-Juni 2004).ISSN: 0215-9687.

Sujadi, Suparjo, Masalah-Masalah Hukum Aktual dalam Wacana Agraria di Indonesia, dalam Jurnal Hukum dan Pembangunan No.1 tahun ke 37 (Januari-Maret 2007). ISSN: 0215-9687.

\section{Internet}

Batampos $<$ http://batampos.co.id/Diiringi-Tor-tor-WargaBlokir-Bandara-Polonia.html >, diakses tanggal 1 Februari 2008. 
FIG: $<$ http://www.fig.net/commission7/reports/cadastre/atatement_on_ca dastre_summary.html >, diakses 1 Februari 2008.

Land Management and Policy Development Project (LMPDP):< http://www.landpolicy.or.id/kajian/13/tahun/2007/bulan/08/tang $\mathrm{gal} / 29 / \mathrm{id} / 27 />$, diakses tanggal 30 Januari 2008. 